ALIA

The Inclusion of Unaccompanied Minors in Italy ${ }^{2}$

Marco Catarci, Matilde Rocchi ${ }^{3}$

\begin{abstract}
The article explores the inclusion of unaccompanied migrant children reaching Italy without their parents or a legal guardian. It aims at presenting the results of a qualitative research conducted in Rome in 2016, through semistructured interviews. The research shows the difficult conditions of such children, arriving to Italy through a perilous and traumatic journey despite their young age. The Italian reception system for unaccompanied migrant children still largely focuses on material needs, while paying little attention to the educational, social and economic needs. Particularly, the quest to send money to their families in the country of origin makes access to education difficult and leads often the children to work irregularly, thus being exploited. Furthermore, the current Italian legal system is not adequate to defend the rights and to support the integration of this particular category of migrants, especially in their transition into adulthood.
\end{abstract}

Keywords: Unaccompanied Minors, interculturalism, intercultural education, migration.

\title{
The unaccompanied migrant child
}

Currently, the presence of unaccompanied migrant minors in Italy is of 23,753. In 2016 their presence was of 25,846 in total, that is $15 \%$ of all the people arriving via the Mediterranean Sea into Italy (Ministry of Labour and Social Policies, 2016; IDOS-UNAR, 2016, pp. 147-150). Unaccompanied migrant children are those who arrive to Italy without their parents or a legal guardian. They are those children that:

\footnotetext{
${ }^{2}$ This article is the product of a collaborative work. In particular, Marco Catarci wrote paragraphs 1, 4.3, 4.4; Matilde Rocchi wrote paragraphs 2,3, 4.1, 4.2, 5.

${ }^{3}$ Department of Education, Roma Tre University.
} 
Not having an Italian or European citizenship [...] they are for various reasons within the State's territory without assistance and parent's or legal guardian's representations, according to what is established by the Italian law (Decree President of the Council of Ministers n. 535/1999, art. 1.2).

According to the Italian law, the state is obliged to include unaccompanied migrant children and grant them a residence permit valid until they reach 18 (Legislative Decree 286/1998, art. 19). The presence of unaccompanied migrant children within the wider context of the European Union seems difficult to quantify, as some countries keep record of only those seeking asylum. In any case, in 2015 there were 90,000 asylum requests from unaccompanied minors in Europe. Within the Italian context, unaccompanied migrant children are often young teens, close to 18 years old, in need of work and economic inclusion. Most of them are 17 years old $(55.2 \%)$, followed by those of 16 years old (26.6\%), and 15 years old (10.4\%). 93.1\% of them are males. The majority of unaccompanied migrant minors in Italy arrive from Egypt (16.2\%), followed by Gambia (13.1\%), and Albania (9.1\%) (Ministry of Labour and Social Policies, 2016).

Table 1 - First Ten Nationalities of Unaccompanied Migrant Children in Italy

\begin{tabular}{|l|c|c|}
\hline Countries of origin & Abs. Value & $\%$ \\
\hline Egypt & 2.801 & 16,2 \\
\hline Gambia & 2.252 & 13,1 \\
\hline Albania & 1.573 & 9,1 \\
\hline Nigeria & 1.456 & 8,4 \\
\hline Eritrea & 1.314 & 7,6 \\
\hline Guinea & 1.141 & 6,6 \\
\hline Ivory Coast & 918 & 5,3 \\
\hline Mali & 857 & 5,0 \\
\hline Somalia & 845 & 4,9 \\
\hline Senegal & 832 & 4,8 \\
\hline
\end{tabular}

Source: Ministry of Labour and Social Policies, 2016: 2

Some of the critical aspects of the presence of unaccompanied migrant children are:

- The prevailing male components (93.1\%) that hides the female components often exposed to trafficking; 
- The high number of untraceable minors, out of any reception structure, who cannot be found within the territory: in 2016 there were 6,508 untraceable minors. Most of them do not enter the reception services and transit within the Italian territory to reach family or relatives in Northern European countries;

- The issue of reaching adulthood, thus losing the legal protection guaranteed to unaccompanied minors by the Italian state, which they are not aware of.

According to the Italian Law (Law n. 189/2002), when reaching adulthood the unaccompanied minor can convert his/her residence permit only if $\mathrm{s} / \mathrm{he}$ has been residing in Italy for at least three years, if $s /$ he has been involved for at least two years in social and civil integration projects, and if s/he holds a working or studying permit. Considering that more than $55.2 \%$ of unaccompanied minors arrive in Italy at the age of 17 years old, it seems clear that it is impossible for most of them to comply with these rules. Following some changes in the Law, as of today minors reaching 18 (including those who are residing in Italy for less than 3 years) can obtain a residence permit for a year waiting to get a regular job, but the problem of reaching adulthood persists modifying substantially the legal condition of the subject without the teens being aware of this. In March 2017 a new law has been issued (S. 2583), establishing that unaccompanied minors arriving in Italy without their families cannot be forcibly removed from the Italian territory and they will have the same rights as European children. The law also disciplines the procedures for age recognition and identification, guaranteeing a common approach at national level.

- The difficulty of moving beyond first reception, focused on primary needs, thus concentrating on interventions responding to social, economic, political and educational needs of unaccompanied migrant children (Accorinti, 2014; Agostinetto, 2017; Anzaldi et al., 2014; Attanasio, 2016; Barone, 2016; Biagioli et al., 2016; Burgio, 2017; Muscarà, 2015; Pizzi, 2016).

In Italy the reception of unaccompanied minors is distributed unevenly across the Italian territory, with bigger concentration of unaccompanied children in the southern regions, particularly in Sicily, first arrival point of minors, hosting $40.9 \%$ of them. 
Education Sciences \& Society, 2/2017

Table 2 - Distribution of unaccompanied migrant children across Italian Regions

\begin{tabular}{|l|c|c|}
\hline Region & Presence & $\%$ \\
\hline Sicily & 7.052 & 40,9 \\
\hline Calabria & 1.460 & 8,5 \\
\hline Emilia Romagna & 1.065 & 6,2 \\
\hline Lombardia & 1.029 & 6,0 \\
\hline Puglia & 907 & 5,3 \\
\hline Lazio & 888 & 5,1 \\
\hline Campania & 853 & 4,9 \\
\hline Sardinia & 711 & 4,1 \\
\hline Friuli Venezia Giulia & 661 & 3,8 \\
\hline Tuscany & 625 & 3,6 \\
\hline Piemonte & 539 & 3,1 \\
\hline Veneto & 315 & 1,8 \\
\hline Basilicata & 301 & 1,7 \\
\hline Liguria & 259 & 1,5 \\
\hline Marche & 194 & 1,1 \\
\hline Abruzzo & 128 & 0,7 \\
\hline Molise & 100 & 0,6 \\
\hline Autonomous Province of Bolzano & 79 & 0,5 \\
\hline Autonomous Province of Trento & 62 & 0,4 \\
\hline Umbria & 14 & 0,1 \\
\hline Valle d'Aosta & 3.245 & 0,0 \\
\hline Total & & \\
\hline
\end{tabular}

Source: Ministry of Labour and Social Policies, 2016: 3

Emergency reception of unaccompanied children implies access to services of emergency and identification. This is followed by the registration of fingerprints, age identification, and reception. In this phase, initial interviews with the children are conducted and an investigation is launched on the family of origin of the children. Emergency services can host a minor for a maximum of 60 days, at the end of which s/he enters in first reception centres, and after, to the second reception services (foster care homes, residential care homes, low-threshold centers, in the case of teens close to adulthood). Within 60 days of their entrance in first reception, a legal guardian should be found through 
whom the child can obtain a residence permit, register to the national health service and access other essential services.

An alternative to public or private reception centers is custody. The unaccompanied minor can be temporarily adopted by a family, by a single person or by a community, in order to guarantee him/her with economic and social support until s/he reaches adulthood.

Unaccompanied migrant children in the Italian context should be granted a personalised integration pathway, including Italian language learning, employment and education opportunities (especially vocational training), and internships, all useful for the future conversion of the residence permit.

\section{Objectives}

The research has been carried out in 2016 in the city of Rome, with the aim of analysing the condition of unaccompanied migrant children within the Italian capital. The specific objectives of the study were:

- investigating unaccompanied migrant children's life stories, with a specific focus on their journeys and their social, educational, economic, political needs;

- analysing unaccompanied migrant children's reception system in the context of Rome;

- highlighting the critical aspects as well as identifying possible ways to improve reception procedures of unaccompanied migrant children.

\section{Methodology}

The research was conducted adopting a qualitative methodology, using semi-structured interviews. 10 key informants were interviewed: 3 unaccompanied migrant children close to adulthood, 3 young migrant adults, one of whom requested asylum, 2 professionals operating in second reception centers in Rome (specifically, an anthropologist and a social worker), 1 educator of a youth community service and 1 social worker operating also in Rome city hall as legal tutor of unaccompanied migrant children.

\section{Results}

The research results are grouped and described according to four macrocategories: 
a) the migratory journey of unaccompanied minors, where the stories about their journeys are described, alongside an identification of the traumatic aspects of such experience;

b) the reception system, especially as it is perceived by unaccompanied minors and the professionals, mainly focusing on criticalities and possible improvements;

c) practices of social integration for unaccompanied migrant children, highlighting the significant gap between policy documents and their implementation;

d) future possibilities of the reception systems and possible improvements.

\section{Migratory Experience}

A meaningful aspect emerging from the children's narratives, and from the professionals' experience, is the journey. For many of them, migrating is the only possibility to reach certain life standards and to have rights that are denied in their countries of origin. The journey is not the same for all of them. There is a difference between those leaving from Egypt, or from the Maghreb area, and those coming from sub-Saharan Africa, often facing a long journey in the desert, with all its risks. A boy coming from Guinea talks about his journey: "The journey I did, when I get out I went to Mali, Algeri, Lybia, but the way I followed, I found a lot of difficulty and I didn't know that it was like that [...] I don't know why this has arrived like this [...]. But I saw one time when I was in Lybia, a brother of mine, also from Guinea, he... died where we were. [...] In Mali I went around by bus and then and...the last bit where there are... the Arabs [...] Where they make a war. I don't even remember when we entered there. [...] They got us. Without eating and drinking. I only remember I was there alone for three days without eating, only water. [...] When they get you, the money you must have them otherwise they kick you [...] Some, they can take and make you sleep in the desert. And we had many many difficulties, but we entered in Algeria with a small track. They freed us and we got out there" (Int. 1).

Often, those who come from Sub-Saharan Africa do not have a precise destination. They embark in the journey to make their lives better, without knowing where they will arrive convinced that any places will be better than the one they come from. On the contrary, the children coming from the Maghreb area, and particularly from Egypt have a diverse and rich imaginary about their next future, as much as their trip to Rome. At the moment, the more representative nationality among unaccompanied migrant children in Italy is the Egyptian. Their "anticipated socialization" is due to the contact 
with members of their community already emigrated, who encourage them to move to Italy while depicting an idyllic situation: "[I wanted to come to Italy] because I call my friend and he said here in Italy there is food, there is money, job, many things... When I come I didn't find anything. I am no happy now" (Int. 4). Another one affirmed: "My parents didn't want... I wanted by force I spoke with my dad and by force I want to go there, because I heard before my friend 'Italy is good, Italy money, come come!' So, then I spoke with my dad and I want to go there" (Int. 3).

The children's desire to travel to follow their friends is not always in line with their parents' will, but the fact that the parents pay for their expensive trip shows their involvement in the child migratory project: "Because in Egypt there is no job. Ugly. Because there is no job for this I come here. Because all my friends are in Italy. I was in touch with them and now I come to Italy. Good. Beautiful. They said good Italy. We all have job. Some studies in foster care houses. I told my parents I wanted to go and they said ok, as you want" (Int. 7).

It seems hard to foresee the end of this cycle, especially considering that those who came in Italy keep nurturing this positive and deviating imaginary only with the purpose of demonstrating that their migratory project was successful. The following is a transcript of a boy coming from Gharbiyya, the Egyptian region where the highest number of unaccompanied minors in Rome come from. He responded to the question about keeping in touch with his friends and what he told them about Italy: "[There are so many of them] because they all say to come. [...] I speak with my friends on Facebook and WhatsApp. [I say to them] that I am happy. Rome beautiful" (Int. 7).

The trip by land and by sea is a traumatic and dangerous experience. It has a high cost that in the stories of the boys is associated to the most dramatic cost: that of human lives. The high economic cost of the trip and the limited dimensions of the boats that carry a high number of human beings, are constant elements in the boys' narratives: "[In the trip we were] maybe 250. All tight up. A lot of fear. All young, we were all under 18, because [...] when under 18 is good, over 18 going to Egypt by plane. They send you back. Only Egyptian, because in Egypt there is no war. We cannot ask for asylum. [...] Many waves. There is no eating eh! Want water? Like this [indicating with the hands a small amount like to say 'a little']. And then Sicily. The boat arrives on land, it turns upside down... and all run. Water up to the knees. Arrived in Augusta. [...] Boat paid 3000 euros in Italy. In Egypt, a lot” (Int. 3).

A similar condition is told by another boy: "First I go to Alexandria and there I take the boat to go to Sicily. To pay 2.025 euro. [We were] 400. No big. You see that blue car and then the other there [indicating two cars closed to each other not so big]. I mean like two cars. That under, the other one up. [...] 
We tight up. Egyptians but also Syria, Lybia. Children, adults, all. [We have arrived after] 8 days. No food. Only a glass of water and small bread" (Int. 7).

Some of the children interviewed also said that they were not aware of the duration and the destination of the journey. Contrary to those leaving Egypt, a boy interviewed from Guinea did not even know that he would have arrived to Italy. From Lybia, thanks to the suggestions of some his acquaintances, he has arrived in Tunisia, and only after being expelled from there, he and his friends embarked to arrive to Italy, about which they did not even know the existence: "In Lybia what I thought is... not to go immediately to Italy [...]. I was with a few friends, so that we talked and they said that we could also go to Tunisia to find a job. We in the boat to go... maybe in Tunisia and we entered there. We left Lybia to enter in Tunisia. And they said to pass, we cannot stay there [and then we embarked for Italy]. But I remembered that we did 11 hours in the sea. And we didn't know where we are going and we are only in the sea to turn and turn [...]. Then we don't know the direction to Italy and then we saw the Spanish boat and they called for help. And then they got us. And then they transferred us on the Italian ship. And then that ship have transferred us in Sicily, in Pozzallo. [...]. The trip on the boat lasted 12 hours. No... the trip on the boat lasted 2 days. [...] 2 days and we entered in Italy" (Int. 1).

The motivations behind the migratory experience are various. The most significant category in the city of Rome is that of economic migrants, with a real project of the family of origin, referring to a middle social class that considers the journey as a real investment. A social worker explained: "What I see is that we do not receive minors with the most precarious situations, or the poorest, $[. .$.$] they come from contexts whereby they can think of migrating and$ covering the cost of the journey. [...] Sometimes the families who are sending their children are families that have experienced a lowering of the quality of their life. [...] The investment for promoting the future generation is migration, rather than buying lands, as they used to do before" (Int. 6). This has been confirmed by an Egyptian boy, to whom this question has been asked clearly: "[My family in Egypt]is not so poor. Even more poor" (Int. 7).

\section{The Reception System}

Once they have arrived in Italy, children are taken care by the reception system, which having to deal with continuous arrivals, is particularly affected. All the boys interviewed transited in Sicily, but in that period (even lasting one year) they did not undergo an educational or employment program; their only activities have been eating and sleeping: "And there there is the Italian boy, takes us all eh! Only Egyptians and going in a big centre. I was there 2 weeks 
and then I go in another centre close to Syracuse. And stayed there one year. First the fingerprints. In Sicily. Nothing. No Speaking. Not doing anything. Only eating and sleeping. There is nothing, no school. One year. Sleeping, eating, playing. One year like that. After I took all my clothes and run away with my friends. Social workers not all good. $10 \%$ good. Small. Sicily no good. Important to speak Italian and they school no. Eating no good. [...] No clothes. Ugly room, not cleaning" (Int. 3).

For some of them the migratory journey is consolidated. From the narratives of relatives or friends it is known that the latest destination is Rome and to arrive you have to take the bus and from the station you have to go to the migration office with papers certifying the age: "I was in Sicily one week, the name I don't remember. We arrived in Sicily, arrived the Police, the big boat take the small ones and then went to foster care home. [And there we did] nothing, eating, drinking and that is it. [I run away] because I didn't like Sicily. I like Rome, I knew it because I have many friends in Rome. I took the bus in Tiburtina [station]. With friends. And then went to the police office. And then I told them I want to eat and sleep and they said ok. And went to residential care. They took to Termini [station] and then went to a big centre. And there we did fingerprints, hospital, ... I had documents when I arrived" (Int. 7).

From the south of Italy, unaccompanied minors go full of hope in the main cities across the country, of which Rome is among the most representatives. But how are they traced in Rome? A professional interviewed argues that they are the ones who showed up, knowing, with the advice of their acquaintances and friends, where they should go: "In Rome, it is not that they are traced. My experience is that the boys know already that being a minor can follow this pathway, $[. .$.$] they are not totally ignorant of their conditions. [...] Once they$ reach Sicily then they run away from the centers in Sicily, and when they come to Rome they are aware that they have to go to the police or to services, that they know from their friends [...]. They are actually not traced by the police, they themselves emerge within the Italian context, as they know that they have the right to a home, so I'd give them a more active connotation. For those who want to emerge, on the other side there are those who transit" (Int. 2).

Despite this, there are children who have not received the support needed and described by the professional reported above, and had difficulties in finding a place to go. One of the children interviewed told about the lack of reception and the absolute precariousness: "The first day I was there. I was in the police office in the morning and they asked me 'do you have papers'? I gave them and they found me unaccompanied minor. They said I cannot take you without the address where you are going to live. I said the social workers in Sicily that send me here gave me only this paper. I don't know your language, I don't know anything, I don't know nothing about migration and I came here. And if you 
tell me that you cannot take me what can I do? I don't know where I'm going, I don't know where to stay, I don't know where to sleep. They told me to get out. I went out. The afternoon at 4 o'clock I came back and I asked if they can help me to have a place to sleep. But they spoke to me badly. That I cannot sleep in the police office and that I cannot have a home" (Int. 1).

According to what the boy said, a big resource is represented by the network of foreign people. There are precise places in every city where the community of foreigners draw together. One of the many places in Rome is Termini Station. Where, without a proper accommodation, a boy interviewed has slept for a week: "I met African people that speak French, friends, I talked about my problem. 'I entered here in Rome but I don't know where to go, to eat, to sleep, to find to eat' [...]. When the night came I went to Termini and I didn't find nobody who could help me to find where to sleep and someone told me that in Termini there are many people that sleep outside and that do not have where to sleep. And I said [that] me too I don't have to sleep. I remember that in Termini I slept a week, like that, outside. [...]. And then some Africans that I found that speak French or my language, some are in Italy for a long time and they know what to do here. They told me to go to via A. to ask for the address" (Int. 1).

Some organisations rooted within the territory of Rome guide unaccompanied migrant children recently arrived in Italy and they direct them in the centres for primary reception $(C p S A)$, and here they officially enter in the network of social services. In these centres, the police (one interviewee will talk about it) collaborate with professionals (such as intercultural mediators and social workers), and once the status of unaccompanied migrant child is ascertained then the child is identified by competent authorities and then assigned to a reception centre. In the case in which it is verified that the person is not under age, s/he risks to be forcibly removed from Italy: "I went to via A. and they gave me the number of a place, that is called [Association] and I went there. And when I went there, they told me: 'then what do we have to do? I have to send you to the Police. From then the rule. If I send you to the police then they take you to the hospital to see whether you are really underage. If you are underage they send you in a centre, and if you are not underage then they send you to the immigration office to give your fingerprints and a paper to leave Italy. If you lie then they will deport you" (Int. 1).

Once the child enters in the reception system, s/he is subject to: first reception and second reception, where s/he can be until 18 years old, provided that $\mathrm{s} / \mathrm{he}$ undergo a professional or educational training. Actually, in this pathway the educational needs of unaccompanied migrant children can be totally glossed over. For example, concerning his schooling experience one interviewee argues that in the centres where he transited for various months, he has attended the Italian course for only one month, despite his desire to 
go to school and learn the language: "I like [to go to school] and do the lower secondary school diploma... find a job, making pizza. All job. [I attended the Italian course for] one month. [In the beginning] I went to the centre [where] there are children and adults, I was there 5 months. And I did not do anything. Eating and sleeping and playing... no school. Then I went outside Rome. I wanted to be transferred because I wanted to go to school [...]. I was 3 months there and only one month in school... Because [I was asking to go to] school, work, and they said only one month. I asked them and they 'yes yes' and instead nothing. I want to do the baker, pizza maker, school... them 'ok it is fine, we do, we do, and then nothing' (Int. 4).

Due to the lack of efficiency of some services, it seems crucial a control in order to verify the children's conditions when they leave the centres, in relation to their language proficiency, their professional competencies, but also practically in relation to their autonomy in the society. Here is what a social worker, operating as a legal guardian in Rome city hall, proposes: "Why don't we do controls when the children get out from the centres? We have a problem, that we fill up all the services in Rome, and even in the province. [...] Only implicit evaluations are done, I would like to do explicit evaluations, with scientific tools. We should do an Italian exam when they leave the centre, if they have done a vocational course, if among their contacts they have Italian numbers, not all but at least half. One once told me that leaving reception is like getting out of your mum's belly. But did they ever go shopping? Do they know how to cook? Due to the growing number of arrivals we are increasingly creating big centers, which look like machines. Then according to a managerial logic, the catering is better than staying with the boy that learns how to cook an omelette. But it is important that s/he learns how to cook an omelette" (Int. 6).

Another critical aspect that should be underlined is related to legal guardianship. In fact, one of the critical aspects revealed by the professionals within the second reception system is the starting of the legal guardianship: "Legal guardianship, that is always the one that arrives significantly late and consequently the access to all the rest of rights is slowed down" (Int. 2).

Finally, it must be highlighted that the critical aspects of the reception system, according to those working in this field, are particularly linked to the increase in the number of unaccompanied migrant children in the last years, which have made precarious the reception service system in Rome.

\section{Beyond Reception}

The research project investigated the activities that unaccompanied migrant minors do and the ways in which they are integrated in the society where they 
intend to live. 'Eating and drinking' is often mentioned by the children in the interviews. But what are the contacts and the exchanges that these children have with the Italian community? A professional indicates the absence of a community dimension, whereby it would be possible to create significant relationships: "I believe we don't have much innovation. These centres are too isolated, and there is not such a dimension, fundamental to social services, of working with the community [...]. Because it is the personal relationship, the one-to-one relationship that allows for feeling a part of a community" (Int. 6).

There are very little occasions in which migrant children deal with their Italian peers and socialize with them, which is fundamental for later steps of their integration. Even if they have been living here for years they often only know their co-nationals. Consequently, the places where they hang out are always the same, and there is the risk of the creation of ghettos where the teens could confine themselves: "Migrant children in Rome gather only in places where you can find migrants. So in Italian language courses participants are all migrant. Municipal community centres deal mainly with migrant children population. This is also determined by the personal choice of the migrant child, $\mathrm{s} / \mathrm{he}$ tends to be with co-nationals. So, it is necessary a specific kind of work to create a relationship with Italians. There was a time when we invited some Italian children once a week... so they hang out together. They added each other on Facebook. But then the children that were here they left the project and they continued to have those friendships. Or with the scouts... But it should be planned, to create a stable long-term relationship. But it always seems forced, when it is isolated. It is not easy to create this kind of relationship. The risk is the detachment of these migrant children" (Int. 5).

Rome is a big city, often badly organised especially for what concerns public transports, so the local community, the neighbourhood, represents a great resource: "Nobody knows them. In the shops, in the bakeries. They call them the children of Lampedusa. None of them goes to buy bread. This is the problem. If you had a centre with six children, and in the morning, you send Mohammed to buy bread and he says 'Hello, good morning, I would like this [kind of bread]'. Maybe he takes the wrong bread and maybe you could send him back. The backer smiles at him and knows who Mohamed is. Integration is like that. We need to have a plan in relation to the territory. [...] What is missing is a strong connection with the territory, the third sector should have an advocacy role, a capacity to activate all the territorial actors" (Int. 6).

The best example in this sense is given by the Egyptian community. The high number of migrants from Egypt implies that all the children and young people arriving here they remain attached to their own community, often following exploitation pathways, already undertaken by those who have arrived earlier. It is a vicious circle: speaking only to their co-nationals, they do 
not learn Italian, so they have difficulties in finding a job and consequently they have to choose a job given by their co-nationals, often in a context of exploitation. This is the case of the two Egyptians interviewed, who are working in a car wash and they just reached 18 years old: "Every day from Monday to Saturday, I wake up at 5 a.m. and I work until 8 p.m. and they pay me no good. 50 euros per week" (Int. 3).

In this perspective, associations and volunteering organisations represent often spaces in which answers to complex problems of children are offered. A boy has learned Italian through a volunteer that for the whole summer went to give him classes: "There are always more people that want to do something for these kids, and doesn't find any space where they can do that institutionally. I am not talking about legal guardianship, but the Sunday lunch. Or groups of students. You could create mixed shared apartments, for students and boys like them" (Int. 6).

However, there is still a very conservative and narrow environment in which not all the employers accept migrant kids, as well as landlords. It is also for this reason that when turning 18 these children have great difficulties in finding a proper house or a job, like a professional argues: "When the boy has to find a job, very often they tell us, no we don't want foreigners, we hire Italians. Or when we were trying to find a house for those who just turned 18 and were getting out of semi-autonomous centres, they told us no, no foreigners... so, there is resistance" (Int. 5).

For this reason, an institutional intervention is required, which would create spaces for migrant teens, within local communities, in the neighbourhoods, where they could live the territory and not only into the structures and places where they are, more or less intentionally, confined. However, their predisposition is surprisingly peaceful. They do not seem disturbed by the sporadic racist attitude of the locals. This makes us understand their great willingness that if it is properly addressed could offer an important contribution to the society: "It doesn't matter to me. If you look at me nicely or in a bad way it doesn't matter for my life. The only thing I have to do and that I like it's to have my way. I follow it" (Int. 1).

\section{Future Perspectives}

A last theme emerged from the research is related to the improvement perspectives of reception. A crucial step implies the safety in the movements of unaccompanied migrant children. To investigate on it is fundamental to look beyond the arrivals and to interrogate the causes that push the children to emigrate, working to prevent further humanitarian disasters. A professional 
interviewed explained: "We have to create a more legal channel to make them come, we cannot say that they arrive by boat and so we receive them. [They come] to make the experience of acquiring new skills and education. If we act in collaboration with their families, it would make the situation better. For many of them it is a social promotion. [...] We should do a transnational intervention. In this office we are responsible for more than 800 unaccompanied migrant children coming from one region of Egypt, which is Gharbiyya and nobody has ever step foot in there. [...] We have to ask ourselves why they came here, where is the family. We should make cooperation project to have the family engaged. [...] I believe the future will be to make project for the protection of childhood in partnership with the countries from where they come from. In the perspective of insuring them trips where they don't risk their lives" (Int. 6).

When turning 18 the child is out of the reception system and should find a house and a job to convert the residence permit. According to the law, the same who were needing subjects become autonomous and adult actors: "The Italian state implies that once the child has turned 18 , s/he has to find a job, a house and should be integrated with the local community [...]. They have to become adults immediately. Something that does not happen in our society. [...] Unaccompanied migrant children at 18 should be already adults, and have a job and a home, sometimes they send money to their families in the country of origin... Something that it seems impossible for an Italian teen" (Int. 5).

Even among the unaccompanied migrant children interviewed in this research, it appears a considerable difference between those who have turned 18 and those who are still under 18. The minor interviewed of 17 years old seemed more enthusiastic and fatalist, because he ignored what is waiting for him once outside of the protection system. Only outside the reception system it is possible to experience the urgency of a job. What happens outside of the reception system is a jump in a hole, to which they are not prepared: "When I turned 18 I hope I can find a job. I have to change house. I still don't know where to go. [This doesn't scare me] I am calm. I fear nothing. I am big. And then I hope I can find work, now I'm doing a course for dry cleaning and then maybe a place to do training... Now I don't have a job, learning, studying. Then we'll see. I hope to find a job" (Int. 7).

On the other hand, those who are already out of the reception system and are in a 'big centre' are afraid for their precarious and uncertain conditions, without any help or protection: "Now I [am] in other centre more than 18 years old, very big, many people. [...] I can stay here 5 months and that's it, out. I look for a house, I need job, by force" (Int. 3).

What kind of adults are those who are leaving the reception centres for unaccompanied migrant children, and what kind of path they have followed? 
Are they ready to deal with what is waiting for them or they will return to the street, and be subjected to exploitation and criminality? In relation to what happens after they turn 18 there are different hypotheses: "After 18 what happens is not clear. [...] It could be that they leave, going in other countries, it could be that they are exploited in criminal networks... I think that for the majority reappears the families and the friends' networks who absorb them soon after having obtained the residence permit and they oblige them to work in a fruit shop without a regular contract, maybe they give them fake papers. Whether there are more dangerous exploitation networks, I don't know" (Int. 6).

Instead, in relation to the questions about their future expectations migrant children answered that they wish to find an easy situation, with working stability, allowing them to have a house or even a car. Someone timidly said: "[In ten years I imagine having] a house, married, a car, a baby. That's it. And yes a good job, as pizza maker or mechanic" (Int. 3).

The jobs mentioned by the children interviewed are all respectable, but not requiring high qualifications (e.g. barman, mechanic, pizza maker, baker). It does not emerge any aspiration to access to education and working opportunities that are guaranteed to many Italian peers. This is an aspect that limits the quality of life that unaccompanied migrant children might have: "Bar. I like the job in the bar. Now I'm doing the course for dry-cleaning and then also the lower secondary school diploma. I want [to achieve] it so [I will find] a good job" (Int. 7).

In this regard, an educator said that the strong family mandate to work represents also an obstacle to the perspective of studying in Italy, postponing employment inclusion: "It is difficult to engage these children in education. When they say to me 'I have to work, because my family has paid for my trip and I have to repay my debt to come to Italy"' (Int. 10).

The resistance to education is determined also from a condition of 'invisibility' lived by the subjects, who, since the beginning, struggle to recognize themselves as people carrying their stories and as being witness of the events occurred during their journey and in their countries: "In the beginning $[\ldots]$ there is an obstacle that they have to [overcome] [...] then they manage to tell their stories, but afterward, afterward, afterward. Also the fact that they always talk in a low voice, that they cannot say their names [...] this is a sign that they cannot recognize themselves as people [...] having their own stories" (Int. 10).

In this perspective, a crucial role on behalf of unaccompanied migrant minors in the Italian system can be attributed to the Territorial Centers for Adult Education (i.e. Centri Provinciali per l'Istruzione degli Adulti - CPIA), that provide first level educational courses (aimed at obtaining the lower secondary school diploma and the certification of the competences related 
to compulsory education), alphabetization courses and learning of Italian as a second language (with the goal of obtaining the certification of Italian language at the A2 level of the Common European Framework of Reference for Languages), second level educational courses (to obtain vocational education diplomas).

Also, some of the children wish for freedom of movement, for travelling freely with the possibility of living in another country, without forgetting the first country receiving them: "I like to do the baker. I like to be a very good baker, to do Italian cakes, English, so good! I imagine that my training, my education, my job will be good. I imagine to be free all over the world. To go where I want, to not go where I don't want. But remember Italy" (Int. 1).

Thus, it arises in a strong way the desire towards personal security and stability. It is impossible to hide that there is a great difference between unaccompanied migrant children's perspectives and those of their Italian peers. None of them can aspire to an education beyond the secondary level, and those who arrived to this point are a minority.

\section{Conclusions}

In conclusion, some final considerations are formulated with some recommendation for improving the reception system of unaccompanied migrant children in Italy.

Firstly, it seems essential the intervention to make safe the travels of unaccompanied migrant children. Actions and partnership projects should be created with countries of origin, in both educational and professional programs. For what concerns the reception procedures it seems necessary to re-think a system that should be more organic and that would foresee an equal distribution of children across the national territory. In the case of the integrated system, the territorial receptions should manage less children with the possibility of offering higher qualitative standards.

A further proposal to avoid the dispersal of unaccompanied migrant children after their arrival, is to have street units, rooted in the territory, and made up by different and trained professionals, with the purpose of tracing the children, to guide them in reception centres. Where these networks exist already, they should be reinforced and distributed more across the national territory, creating also information offices in the big cities where the children go.

Another practice that should be encouraged, considering the age of unaccompanied migrant children, is the custody. In order to establish such practice, the bureaucracy related to it should be more accessible and efficient, 
in order to accelerate the schedule and to guarantee the children an adequate staying in families, whereby the inclusion with the territory is facilitated.

An adequate and rigorous control of the reception system looks also essential. Verification instruments are needed to understand what are the tools that are effectively available for the teens that leave foster care when they are 18: for example, an exam of Italian, a prove of the residence permits, checking the courses and the training attended by the children, their participation to sport, social and cultural activities.

For what concerns the integration and inclusion of unaccompanied migrant children within the territory, the services and centres where they transit are not so open and active in community building. For this reason, the location of the centres is also important. Reception centres should be placed in areas with services, shops, public transports, libraries, parks and sport facilities.

Finally, on the educational level, it is necessary to create more adequate channels within the education system, starting from a greater awareness of the needs of unaccompanied migrant children. It is necessary to emphasize the voices and the initiatives of unaccompanied migrant children, in order to make them feel as active subjects with their own determination, and not only clients in a system that offers them food and shelter, a greater engagement of the children in their very own biographical projects.

\section{References}

Accorinti M. (2014), Politiche e pratiche sociali per l'accoglienza dei minori non accompagnati in Italia, Rome: Consiglio Nazionale delle Ricerche.

Agostinetto L. (2017), Minori stranieri non accompagnati e richiedenti asilo, in Fiorucci M., Pinto Minerva F., Portera A., Gli alfabeti interculturali, ETS, Pisa, pp. 439-454.

Anci, Caritas italiana, Cittalia, Fondazione Migrantes, SPRAR, UNHCR (2016), Rapporto sulla protezione internazionale in Italia 2016, Rome.

Anzaldi A., Guarnier T., eds. (2014), Viaggio nel mondo dei minori stranieri non accompagnati: un'analisi giuridico-fattuale - Volume I - Il sistema dell'accoglienza, Rome: Fondazione Basso.

Attanasio L. (2016), Il bagaglio. Migranti minori non accompagnati: il fenomeno in Italia, i numeri, le storie, Rome: Albeggi.

Barone L. (2016), L'accoglienza dei minori stranieri non accompagnati: tra norma giuridica e agire sociale, Palermo: Key editore.

Biagioli R., Lischi L., Papa A. (2016), Le attuali emergenze pedagogiche: i minori stranieri non accompagnati. Indagine nelle scuole della Regione Toscana, Firenze: Regione Toscana, pp. 7-118.

Burgio G. (2017), Bodies for sale. Migration and sex work, in "Pedagogia Oggi”, n. 1/2017. 
Giovanetti M., ed. (2016), I comuni e le politiche di accoglienza dei minori stranieri non accompagnati, Rome.

IDOS-Study and Research Centre/Statistical Dossier on Immigration, UNAR-National Office Against Racial Discrimination. (2016). Dossier Statistico Immigrazione 2016. Rome: IDOS.

Ministry of Labour and Social Policy (2016). Report Mensile Minori Stranieri Non Accompagnati (Msna) in Italia Dati Al 30 novembre 2016, http://www.lavoro. gov.it/temi-e- priorita/immigrazione/focus-on/minori-stranieri/Documents/ReportMSNA-30112016.pdf (retrieved on 09/02/2017).

Muscarà M. (2015), Minori stranieri non accompagnati e diritto all'istruzione visti da una terra di frontiera. il caso Sicilia, in Tomarchio M., Ulivieri S., Pedagogia militante. Diritti, culture, territori, Edizioni ETS, Pisa 2015, pp. 204-210.

OXFAM (2016), Rapporto sulla condizione dei minori stranieri non accompagnati, Arezzo: OXFAM

Pizzi F. (2016), Minori che migrano da soli. Percorsi di accoglienza e sostegno educativo, Brescia: La Scuola.

Save The Children Italia (2016), Minori migranti: in viaggio attraverso la rete. Rischi e opportunità di internet dalla voce degli adolescenti stranieri che arrivano in Italia da soli, Rome.

Study and Research Centre/Statistical Dossier on Immigration-IDOS, National Office Against.

Terres de Hommes, Progetto Faro (2012), Guida Psicosociale per operatori impegnati nell'accoglienza dei Minori Stranieri non accompagnati, Milan. 